\title{
Medijacijski učinak samoefikasnosti u odnosu između znanja nastavnika o homoseksualnosti i pružanja podrške homoseksualnim učenicima
}

\author{
Helena Pađen ${ }^{1}$ i Aleksandra Huić ${ }^{2}$ \\ ${ }^{1}$ SELECTIO d. o. o., Zagreb, Hrvatska \\ ${ }^{2}$ Sveučilište u Zagrebu, Filozofski fakultet, Odsjek za psihologiju, Zagreb, Hrvatska
}

\begin{abstract}
Sažetak
Cilj je istraživanja bio ispitati znanje srednjoškolskih nastavnika o homoseksualnoj orijentaciji te istražiti u kakvome su odnosu znanje, samoefikasnost u radu s homoseksualnim učenicima i čestina uključivanja u podržavajuća ponašanja. Ispitivanje je provedeno online, a sudjelovalo je 267 srednjoškolskih nastavnika. Korištene su Skala znanja o homoseksualnoj orijentaciji, Skala samoefikasnosti u radu s homoseksualnim učenicima i Skala podržavajućih ponašanja prema učenicima homoseksualne orijentacije. Rezultati pokazuju da nastavnici imaju umjereno znanje o homoseksualnoj orijentaciji te vrlo često odabiru odgovor $N e$ znam. Rijetko se uključuju u podržavajuća ponašanja prema homoseksualnim učenicima, a njihov je osjećaj samoefikasnosti u radu s njima umjeren. Pritom osjećaju viši stupanj sigurnosti u mogućnost nošenja sa situacijama nasilja na osnovi seksualne orijentacije nego u mogućnost poučavanja učenika o temi homoseksualnosti. Znanje i samoefikasnost u nošenju s nasiljem na osnovi seksualne orijentacije i samoefikasnost u poučavanju o homoseksualnoj orijentaciji značajno predviđaju čestinu uključivanja u podržavajuća ponašanja. Što nastavnici imaju veće znanje o homoseksualnosti, to se češće uključuju u podržavajuća ponašanja, a ta je veza posredovana većom samoefikasnošću u poučavanju o homoseksualnim temama, no ne i većom samoefikasnošću u nošenju s nasiljem. Takvi rezultati ukazuju na važnu ulogu znanja i samoefikasnosti u čestini uključivanja u podržavajuća ponašanja za homoseksualne učenike koji su tijekom srednje škole u vrlo ranjivoj fazi i potrebna im je socijalna podrška.
\end{abstract}

Ključne riječi: homoseksualna orijentacija, znanje o homoseksualnoj orijentaciji, samoefikasnost, podržavajuća ponašanja, srednjoškolski nastavnici

\section{Uvod}

Unatoč postojećim zakonskim okvirima koji štite osobe homoseksualne orijentacije u Hrvatskoj istraživanja stavova opće javnosti te svakodnevnih iskustava

Helena Pađen, SELECTIO d.o.o., Strojarska cesta 20, 10000 Zagreb, Hrvatska. E-pošta: helena.padjen@gmail.com

Aleksandra Huić, Odsjek za psihologiju, Filozofski fakultet, Sveučilište u Zagrebu, Ivana Lučića 3, 10000 Zagreb, Hrvatska. E-pošta: ahuic@ffzg.hr 
homoseksualnih muškaraca i lezbijki pokazuju da hrvatsko društvo ne prihvaća osobe svih seksualnih orijentacija (Jugović i Ančić, 2013; Štulhofer i Rimac, 2009; Takács i Szalma, 2013). Homoseksualne osobe izložene su fizičkomu i verbalnom nasilju, kao i diskriminaciji prilikom zapošljavanja i odbijanju usluga (Jugović i Pikić, 2006; Kamenov i sur., 2016). Negativan socijalni kontekst u kojemu žive povezan je s njihovim lošijim mentalnim zdravljem (Meyer, 2003), što potvrđuju i hrvatski podaci (Kamenov i sur., 2016). Spomenuti se negativan utjecaj pojavljuje već u adolescenciji (Hatzenbuehler, 2009).

Spoznaja se o sklonosti istomu spolu kod dječaka pojavljuje u dobi između 11. i 12. godine, a kod djevojčica između 14. i 15. godine (APA, 2008; Diamond, 1998). Mnogi od njih tada doživljavaju unutarnju borbu, pogotovo pri nedostatku socijalne podrške. Seksualna orijentacija ne predstavlja rizik za razvoj negativnih ishoda, već su psihički problemi mladih homoseksualne orijentacije povezani s diskriminacijom i uznemiravanjem koje doživljavaju te s negativnim interakcijama s vršnjacima i odraslima (Russell i sur., 2001). S obzirom na količinu vremena koju mladi te dobi provode u školi, važno im je osigurati sigurno, podržavajuće i nediskriminirajuće školsko okruženje.

Jednu od ključnih uloga u oblikovanju toga okruženja imaju nastavnici. De Witte i suradnici (2019) nalaze da stavovi nastavnika prema osobama homoseksualne orijentacije reflektiraju stavove opće populacije. Istraživanja pokazuju da nastavnici slabo pridonose stvaranju inkluzivne školske klime za učenike homoseksualne orijentacije. Podaci prikupljeni tijekom američkoga nacionalnog istraživanja u kojemu je sudjelovalo 10528 američkih učenika pokazuju da je $85.2 \%$ američkih učenika koji pripadaju homoseksualnoj, biseksualnoj i transrodnoj populaciji (LGBT) bilo verbalno uznemiravano zbog svoje seksualne orijentacije, dok ih je $27 \%$ bilo fizički zlostavljano (Kosciw i sur., 2016). Nadalje, 57.6 \% LGBT učenika koji su bili uznemiravani ili zlostavljani nisu taj događaj prijavili školskomu osoblju, najčešće jer su sumnjali da će doći do efikasne intervencije. Više od polovice učenika (56.2 \%) izjavilo je da je od svojih učitelja ili ostalih članova školskoga osoblja čulo pogrdne riječi koje opisuju homoseksualne osobe. Prema rezultatima istoga istraživanja LGBT učenici koji su često uznemiravani zbog svoje seksualne orijentacije češće su bili depresivni i imali su nisko samopouzdanje, tri puta češće propuštali su školsku nastavu, imali su niži prosjek ocjena i rjeđe su planirali nastaviti školovanje.

Iako nismo pronašli hrvatska istraživanja koja bi ispitivala stavove i ponašanja nastavnika prema homoseksualnim učenicima, postojeći podaci ukazuju na to da LGBT učenici u hrvatskim školama ne uživaju u sigurnome ozračju. Retrospektivni izvještaji odraslih osoba neheteroseksualne orijentacije pokazuju da su škola i fakultet treći najčešći kontekst u kojemu su tijekom života doživjeli diskriminaciju (Milković, 2003). Istraživanja stavova srednjoškolaca o osobama homoseksualne orijentacije ukazuju na nisko znanje o homoseksualnoj orijentaciji i veliku sklonost diskriminaciji homoseksualnih učenika. U istraživanju provedenome na 
reprezentativnome uzorku učenika završnih razreda srednjih škola u Hrvatskoj čak $45.2 \%$ učenika i $12.3 \%$ učenica u potpunosti se slaže s tvrdnjom da je homoseksualnost neka vrsta bolesti, a $45.6 \%$ učenika i $27.7 \%$ učenica homoseksualnim bi osobama zabranilo javno nastupanje jer na taj način loše utječu na odgoj mladih (GONG, 2010). U drugome istraživanju više od polovice srednjoškolaca slagalo se $\mathrm{s}$ tvrdnjama da je homoseksualnost izbor i da osobe same biraju spol koji će ih privlačiti, a njih $50 \%$ smatra da je homoseksualnost neki oblik poremećaja i bolesti (Kuliš i Petrović, 2018). Rezultati istoga istraživanja pokazuju da je nazivanje pogrdnim imenima najprisutniji oblik nasilja u školama te je čak $53 \%$ učenika često ili nekoliko puta svjedočilo verbalnomu nasilju prema homoseksualnim osobama, a $13 \%$ barem je jednom svjedočilo lakšemu tjelesnom zlostavljanju. Hodžić i Bijelić (2012) navode da se u takvim situacijama učenici koji su žrtve nasilja najčešće ne obraćaju za pomoć nastavnicima i stručnim suradnicima zbog straha od odbacivanja i osude. Čini se ni da sami školski djelatnici nemaju dovoljno informacija, znanja i vještina kako pružati podršku učenicima. Prema izvještaju pravobraniteljice o ravnopravnosti spolova (2015) teme povezane sa seksualnom orijentacijom najviše se izbjegavaju u školama, a i sami učenici navode da tijekom školovanja nisu imali prilike čuti o homoseksualnoj orijentaciji (Kuliš i Petrović, 2018).

Inozemna istraživanja pokazuju da je odnos učenika homoseksualne orijentacije s nastavnicima posebno važan za njihovu dobrobit u školi. Russell i suradnici (2001) odnose s nastavnicima identificirali su kao važnije čak i od odnosa s roditeljima ili s vršnjacima u objašnjavanju količine školskih problema koje takvi homoseksualni učenici doživljavaju i zaključili da podrška nastavnika može pomoći u njihovoj prevenciji. Slično tomu, u istraživanju Murdocka i Bolcha (2005) učenici koji su školsku klimu opisivali kao homofobnu, no istovremeno su imali podršku nastavnika, izvještavali su o jednako visokome osjećaju pripadnosti kao i učenici koji su školsku klimu opisivali kao tolerantnu. Također, učenici koji mogu identificirati veći broj podržavajućih članova školskoga osoblja osjećaju se sigurnije u školi, rjeđe propuštaju školsku nastavu, imaju bolje ocjene i češće planiraju upisati fakultet (Kosciw i sur., 2016). Ti rezultati upućuju na to da su ponašanja i podrška nastavnika važni prediktori čitavoga niza pozitivnih ishoda kod homoseksualnih učenika.

Istraživanja također pokazuju da nastavnici često nisu aktivni u pružanju podrške homoseksualnim učenicima, a u situacijama homofobnoga zlostavljanja nerijetko ni ne reagiraju. $U$ američkome nacionalnom istraživanju Kosciwa i suradnika (2016) $63.5 \%$ LGBT učenika izvijestilo je o tome da nastavnici i drugo školsko osoblje nisu ništa poduzeli u vezi incidenta zlostavljanja za koji su im se učenici obratili. Osim toga, u istraživanju McCabea i suradnika (2013), provedenome na američkome uzorku nastavnika i školskih psihologa, 62 \% sudionika reklo je da nikad ili vrlo rijetko zagovara i brani LGBT učenike. Istraživanja uzroka koji su u podlozi takvih propusta u reagiranju nastavnika istaknula su ulogu individualnih 
faktora kao što su stavovi, vjerovanja i znanja o seksualnoj orijentaciji (Savage i sur., 2004; Whitman i sur., 2007).

Nastavnici s pozitivnijim stavovima prema homoseksualnim osobama češće izražavaju namjere reagiranja u situacijama međusobnoga zlostavljanja učenika zbog njihove seksualne orijentacije (Collier i sur., 2015; Swanson i Gettinger, 2016). Osim stavova, znanje nastavnika o homoseksualnim osobama, kojemu se posvećuje premalo pažnje u takvim istraživanjima, povezano je $s$ više ponašanja kojima se podržavaju osobe istospolne seksualne orijentacije (Swanson i Gettinger, 2016). I Hall (2006) je među najčešćim uzrocima zbog kojih nastavnici u školama ne ističu LGBT teme i probleme kao važne identificirao nedostatak znanja, vještina i upućenosti u to područje.

Drugi konstrukt koji može objasniti ponašanje nastavnika prema homoseksualnim učenicima nastavnička je samoefikasnost. Općenito, samoefikasnost se definira kao vjerovanje osobe u svoje sposobnosti nošenja sa situacijom, uzimajući u obzir vještine koje posjeduje i okolnosti s kojima je suočena (Bandura, 1994). Samoefikasnost nastavnika pozitivno je povezana s kvalitetom razrednih procesa, odnosno $\mathrm{s}$ vjerojatnošću njihove intervencije u situacijama zlostavljanja općenito (Howard i sur., 2001; Yoon, 2004), ali i u situacijama međusobnoga zlostavljanja učenika na osnovi seksualne orijentacije (Collier i sur., 2015; Greytak i Kosciw, 2014; Nappa i sur., 2017). Važno je naglasiti da se samoefikasnost može steći ili promijeniti, a najdjelotvorniji je način tijekom iskustava ovladavanja konkretnom aktivnošću. Prema Reeve (2010) osnaživanje se sastoji, između ostaloga, i od posjedovanja znanja, no nisu pronađena istraživanja koja bi se bavila odnosom znanja nastavnika o homoseksualnoj orijentaciji i njihove samoefikasnosti u školskome kontekstu.

Osim toga, iako i teorije i istraživanja pokazuju da je školsko okruženje izrazito važno za dobrobit homoseksualnih učenika, općenito nedostaje istraživanja koja bi pokušala identificirati faktore koji su kod školskih nastavnika prediktivni za stvaranje sigurne i podržavajuće školske okoline za homoseksualne učenike. Dodatno, u Hrvatskoj se tomu pitanju dosad nije posvećivala istraživačka pažnja. Stoga je ovo istraživanje usmjereno na znanja srednjoškolskih nastavnika o homoseksualnosti, na njihovu samoefikasnost u radu s homoseksualnim učenicima te na to koliko se često uključuju u različita ponašanja kojima mogu štititi i zagovarati prava homoseksualnih učenika. Zanimalo nas je i hoće li nastavnici izabirati produbljivanje svojega znanja o temi homoseksualne orijentacije te ovisi li taj njihov izbor o prethodnome znanju. Usto, istraženo je i u kakvome su odnosu to znanje, samoefikasnost i ponašanja, zbog čega su postavljena dva dodatna istraživačka problema: a) ispitati predviđaju li znanje nastavnika o homoseksualnoj orijentaciji i njihova samoefikasnost učestalost kojom se upuštaju u podržavajuća ponašanja prema homoseksualnim učenicima; b) provjeriti je li samoefikasnost značajan posrednički mehanizam u podlozi odnosa znanja i podržavajućih ponašanja. Pretpostavljeno je da će bolje nastavničko znanje i viši osjećaj samoefikasnosti 
značajno predviđati njihovo veće uključivanje u pozitivna, podržavajuća ponašanja prema homoseksualnim učenicima te da će osjećaj samoefikasnosti biti značajan posrednički mehanizam toga odnosa.

\section{Metoda}

\section{Sudionici}

U istraživanju je sudjelovalo 267 srednjoškolskih nastavnika ( $83.9 \%$ žena i $16.1 \%$ muškaraca) u dobi od 24 do 64 godine $(M=41.94 ; S D=9.593)$. Najveći dio sudionika radi u srednjim do većim hrvatskim gradovima ( $51.7 \%$ ), $23.8 \%$ u Zagrebu te $24.5 \%$ u manjim mjestima ili selima. U četverogodišnjoj strukovnoj školi predaje $65.9 \%$ sudionika, u gimnaziji $40.4 \%$, dok $26.6 \%$ sudionika predaje u trogodišnjoj strukovnoj školi. Prevladavaju nastavnici koji su završili fakultet humanističkoga $(32.2 \%)$ i društvenog $(30.3 \%)$ područja, slijede oni iz prirodnih $(19.3 \%)$ te biotehničkih znanosti (1.5\%).

\section{Instrumenti}

Skala znanja o homoseksualnoj orijentaciji konstruirana je za potrebe ovoga istraživanja, a na temelju najčešćih mitova o homoseksualnim osobama preuzetih od Kamenov i suradnika (2016) te na temelju Skale informiranosti o homoseksualnoj orijentaciji (Wells i Franken, 1987) korištene u istraživanju Aldersona i suradnika (2009). Odabrane su one čestice koje se sadržajno odnose na prevalenciju i razvoj homoseksualne orijentacije te na ponašanje osoba homoseksualne orijentacije. Za ukupno 14 tvrdnji sudionici odgovaraju jesu li točne, netočne ili ne znaju odgovor (v. Tablicu 1. u Rezultatima). Pouzdanost tipa unutarnje konzistencije je zadovoljavajuća $(\alpha=.81)$.

Skala samoefikasnosti u radu s homoseksualnim učenicima također je konstruirana za potrebe ovoga istraživanja. Iz Skale nastavničke samoefikasnosti u slučajevima zlostavljanja Gregusa i suradnika (2017) preuzete su čestice koje su imale najviša faktorska zasićenja te su prilagođene specifično za slučaj zlostavljanja učenika homoseksualne orijentacije. Njima su dodane čestice povezane $\mathrm{s}$ poučavanjem o seksualnoj orijentaciji osmišljene za potrebe istraživanja. Prilikom konstruiranja skale vodilo se računa o Bandurinim (2006) smjernicama za konstruiranje skala samoefikasnosti. Skala sadrži deset čestica, a sudionici na ljestvici od 0 (uopće ne mogu) do 100 (u potpunosti mogu) označavaju stupanj u kojemu su sigurni da mogu obavljati navedena ponašanja. Prilikom provođenja faktorske analize metodom zajedničkih faktora identificirana su dva interpretabilna kosokutna faktora koji zajedno objašnjavaju $67.98 \%$ varijance. Prvi je faktor samoefikasnost u nošenju s nasiljem na osnovi seksualne orijentacije (7 čestica; $\alpha=.92$; npr. Siguran sam da bih, da vidim učenika da zadirkuje drugoga učenika zbog njegove seksualne orijentacije, znao što učiniti), a drugi je faktor 
samoefikasnost u poučavanju o homoseksualnoj orijentaciji (3 čestice; $\alpha=$.94; npr. Siguran sam da sam sposoban organizirati učeničke rasprave na temu homoseksualne orijentacije). Ukupan rezultat računa se kao prosjek, pri čemu veći rezultat na oba faktora označava veću samoefikasnost.

Skala podržavajućih ponašanja prema učenicima homoseksualne orijetnacije (Swanson i Gettinger, 2016; engl. Teacher roles to support LGBT youth) sadrži deset čestica koje navode različita ponašanja kojima nastavnici mogu zauzeti podržavajuću ulogu za homoseksualne učenike. U originalu korišteni izraz LGBT zamijenjen je izrazom homoseksualno u odgovarajućemu jezičnom obliku. Primjeri su nekih čestica U situacijama kad učenici ili kolege/članovi osoblja koriste homofobne izraze, odmah reagiram i Trudim se da su homoseksualne teme reprezentirane $u$ nastavnome sadržaju i raspravama. Sudionici odgovaraju koliko se često upuštaju u navedena ponašanja na ljestvici od 1 (gotovo nikad) do 4 (gotovo uvijek). Faktorskom analizom metodom zajedničkih faktora ekstrahiran je jedan zajednički faktor koji objašnjava $44.3 \%$ varijance. Ukupni je rezultat formiran kao prosjek odgovora, pri čemu veći rezultat označava češća podržavajuća ponašanja $(\alpha=.86)$.

\section{Postupak}

Istraživanje je provedeno online u svibnju 2018. godine, uz potvrdu Etičkoga povjerenstva Odsjeka za psihologiju Filozofskoga fakulteta Sveučilišta u Zagrebu, a putem e-adresa pronađenih na mrežnim stranicama škola, na društvenim mrežama te u određenim grupama na Facebooku koje okupljaju nastavnike i stručne suradnike. Nakon što su dali svoj informirani pristanak, sudionici su pristupili upitniku za rješavanje kojega im je u prosjeku bilo potrebno 15 minuta. Sve su se stranice u upitniku, osim onih koje su sadržavale demografska pitanja, pojavljivale slučajnim redoslijedom. Nakraju su sudionici mogli odabrati žele li pročitati edukativni materijal koji je sadržavao rezultate dosadašnjih istraživanja o iskustvima LGBT učenika u školskome okruženju u SAD-u.

\section{Rezultati}

\section{Znanje nastavnika o homoseksualnoj orijentaciji}

U prvome koraku rezultati na mjeri znanja rekodirani su tako da svaki ispravan odgovor nosi 1 bod, a pogrešan odgovor ili odgovor Ne znam 0 bodova (v. Tablicu 1.). Tako su sudionici mogli dobiti najmanje 0 , a najviše 14 bodova ako su dali sve ispravne odgovore. Distribucija ukupnih rezultata (Slika 1.) pokazuje da je $1.9 \%$ sudionika postiglo rezultat 0 , dok je $0.8 \%$ sudionika imalo rezultat 14 . Prosječni je rezultat bio $M=8.25(S D=3.34)$, odnosno $59 \%$ ispravnih odgovora, a najčešće su nastavnici imali 10 ispravnih odgovora. 


\section{Slika 1.}

Frekvencija sudionika ovisno o broju ispravnih odgovora na Skali znanja o homoseksualnoj orijentaciji $(N=264)$

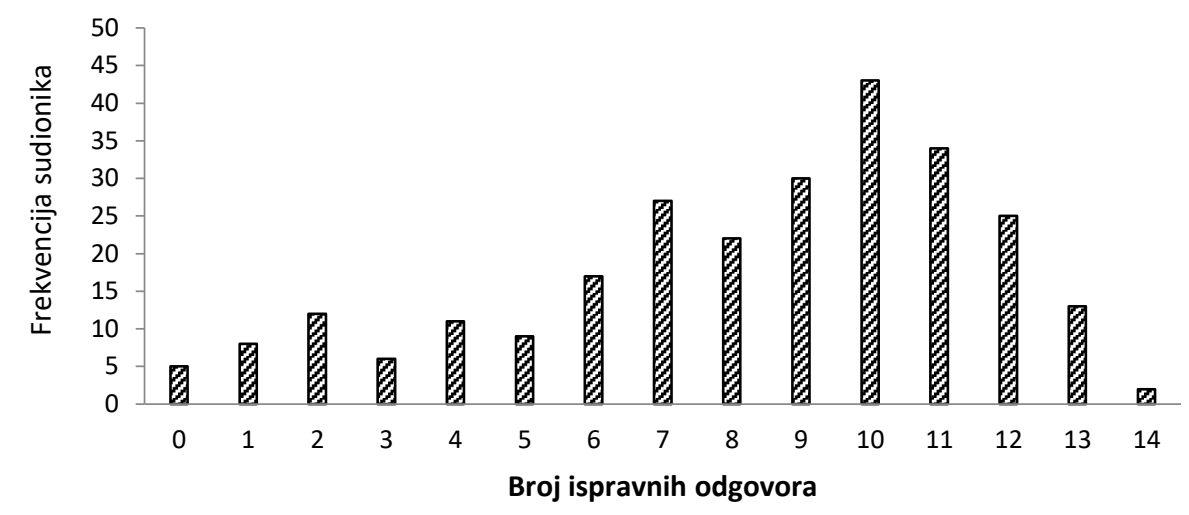

Iz Tablice 1. vidljivo je da su sudionici najveći postotak ispravnih odgovora dali na čestici Seksualna orijentacija može se promijeniti terapijom, molitvom ili lijekovima, gdje njih 86.5 \% zna da je to netočno, a slijedi je čestica Ljudi postaju homoseksualci ako su bili spolno zlostavljani kao djeca s $82.4 \%$ ispravnih odgovora da je to netočno. To su ujedno bile i čestice na kojima su sudionici pokazali najmanji stupanj nesigurnosti u svoje znanje jer je njih $12.4 \%$, odnosno $17.6 \%$ odabralo odgovor $\mathrm{Ne}$ znam, a nitko ili gotovo nitko od sudionika nije odabrao pogrešan odgovor.

Najveći stupanj nesigurnosti u svoje znanje nastavnici su pokazali na česticama Heteroseksualni nastavnici spolno zlostavljaju svoje učenike ili studente češće od homoseksualnih nastavnika (52.8\% odgovora Ne znam), Homoseksualci češće mijenjaju seksualne partnere od heteroseksualaca (47.2\% odgovora $\mathrm{Ne}$ znam) te Homoseksualne osobe češće su zaražene HIV-om i drugim spolnim bolestima od heteroseksualnih osoba (45.7 \% odgovora $\mathrm{Ne}$ znam). Općenito, kad je riječ o nesigurnosti nastavnika u svoje znanje o homoseksualnosti, samo $10.5 \%$ sudionika nije nijednom odabralo odgovor $\mathrm{Ne}$ znam, a prosjek odgovora $\mathrm{Ne}$ znam iznosio je $M=3.7(S D=2.99)$. Iako je najveći broj sudionika izrazio svoju nesigurnost tri puta tijekom odgovaranja na čestice iz Skale znanja, njih čak $45.3 \%$ odgovorilo je $\mathrm{Ne}$ znam četiri puta ili više.

Čestica Heteroseksualni nastavnici spolno zlostavljaju svoje učenike ili studente češće od homoseksualnih nastavnika (što je točno) dobila je i najmanje ispravnih odgovora, a najviše pogrešnih odgovora. Visok postotak sudionika (oko 30 \%) pogrešnim smatra da je Homoseksualce (...) lako prepoznati prema izgledu, stilu ili načinu izražavanja. Sličan postotak sudionika pogrešno je odgovorio i da je čestica Uzrok homoseksualne orijentacije jako je kompleksno pitanje na koje trenutno nema odgovora netočna. 


\section{Tablica 1.}

Postoci ispravnih $i$ pogrešnih odgovora te odgovora $\mathrm{Ne}$ znam na upitniku znanja o homoseksualnoj orijentaciji $(N=267)$

\begin{tabular}{|c|c|c|c|}
\hline & $\begin{array}{l}\text { Ispravan } \\
\text { odgovor }\end{array}$ & $\begin{array}{l}\text { Pogrešan } \\
\text { odgovor }\end{array}$ & $\begin{array}{c}\mathrm{Ne} \\
\text { znam }\end{array}$ \\
\hline $\begin{array}{l}\text { 1. Za djecu koju odgajaju homoseksualni roditelji } \\
\text { vjerojatnije je da će biti homoseksualne orijentacije od } \\
\text { one koju odgajaju heteroseksualni roditelji. }(\mathrm{N})\end{array}$ & 70.8 & 4.1 & 25.1 \\
\hline $\begin{array}{l}\text { 2. U posljednjih } 25 \text { godina homoseksualnost je postala } \\
\text { češća. }(\mathrm{N})\end{array}$ & 56.6 & 19.1 & 24.3 \\
\hline $\begin{array}{l}\text { 3. Većina homoseksualnih žena i muškaraca želi biti } \\
\text { heteroseksualna. }(\mathrm{N})\end{array}$ & 56.6 & 3.7 & 39.7 \\
\hline $\begin{array}{l}\text { 4. Većina homoseksualaca želi nagovoriti ili privući } \\
\text { druge u homoseksualni stil života. }(\mathrm{N})\end{array}$ & 76.0 & 6.0 & 18.0 \\
\hline $\begin{array}{l}\text { 5. Heteroseksualni nastavnici spolno zlostavljaju svoje } \\
\text { učenike ili studente češće od homoseksualnih } \\
\text { nastavnika. (T) }\end{array}$ & 10.5 & 36.7 & 52.8 \\
\hline $\begin{array}{l}\text { 6. Kad bi mediji pozitivno prikazivali homoseksualnost, } \\
\text { to bi utjecalo na mlade te bi oni češće postajali } \\
\text { homoseksualci. }(\mathrm{N})\end{array}$ & 71.2 & 8.2 & 20.6 \\
\hline $\begin{array}{l}\text { 7. Homoseksualce je lako prepoznati prema izgledu, } \\
\text { stilu ili načinu izražavanja. }(\mathrm{N})\end{array}$ & 55.4 & 29.2 & 15.4 \\
\hline $\begin{array}{l}\text { 8. Homoseksualci nisu dobri uzori za djecu i mogli bi im } \\
\text { psihološki naštetiti, kao i utjecati na normalan spolni } \\
\text { razvoj. }(\mathrm{N})\end{array}$ & 79.4 & 5.6 & 15.0 \\
\hline $\begin{array}{l}\text { 9. Uzrok homoseksualne orijentacije jako je kompleksno } \\
\text { pitanje na koje trenutno nema odgovora. (T) }\end{array}$ & 46.8 & 30.0 & 23.2 \\
\hline $\begin{array}{l}\text { 10. Ljudi postaju homoseksualci ako su bili spolno } \\
\text { zlostavljani kao djeca. }(\mathrm{N})\end{array}$ & 82.4 & 0 & 17.6 \\
\hline $\begin{array}{l}\text { 11. Homoseksualci češće mijenjaju seksualne partnere } \\
\text { od heteroseksualaca. }(\mathrm{N})\end{array}$ & 35.5 & 17.4 & 47.2 \\
\hline $\begin{array}{l}\text { 12. Homoseksualne osobe češće su zaražene HIV-om i } \\
\text { drugim spolnim bolestima od heteroseksualnih } \\
\text { osoba. }(\mathrm{N})\end{array}$ & 27.3 & 27.0 & 45.7 \\
\hline $\begin{array}{l}\text { 13. Osoba može odabrati želi li biti homoseksualne } \\
\text { orijentacije. }(\mathrm{N})\end{array}$ & 68.5 & 15.0 & 16.5 \\
\hline $\begin{array}{l}\text { 14. Seksualna orijentacija može se promijeniti terapijom, } \\
\text { molitvom ili lijekovima. }(\mathrm{N})\end{array}$ & 86.5 & 1.1 & 12.4 \\
\hline
\end{tabular}

Napomena: U zagradama je navedeno je li pojedina tvrdnja točna (T) ili netočna $(\mathrm{N})$; točnost tvrdnji utvrđena je na temelju službenih materijala Američke psihološke asocijacije (APA, 2008, 2011).

Budući da su sudionici na samome kraju upitnika mogli odabrati žele li pročitati nalaze dosadašnjih istraživanja o iskustvima homoseksualnih učenika u školama, zanimalo nas je razlikuju li se možda sudionici koji su odabrali edukativni materijal od onih koji to nisu učinili u svojemu znanju o homoseksualnoj orijentaciji i u tome 
koliko su ukupno puta odabrali odgovor Ne znam (sigurnost u znanje). Kao što je vidljivo na Slici 2., sudionici koji su na kraju upitnika odabrali da ih zanima edukativni materijal imali su veće znanje $(t=4.85, p<.001)$ te manji ukupni broj odgovora $\mathrm{Ne}$ znam u odnosu na sudionike koje nije zanimao edukativni materijal $(t=-3.54, p<.001)$.

\section{Slika 2.}

Prikaz prosječnih rezultata na Skali znanja o homoseksualnoj orijentaciji te prosječne čestine biranja odgovora $\mathrm{Ne}$ znam ovisno o tome jesu li ili nisu nastavnici odabrali pročitati edukativni materijal na kraju upitnika

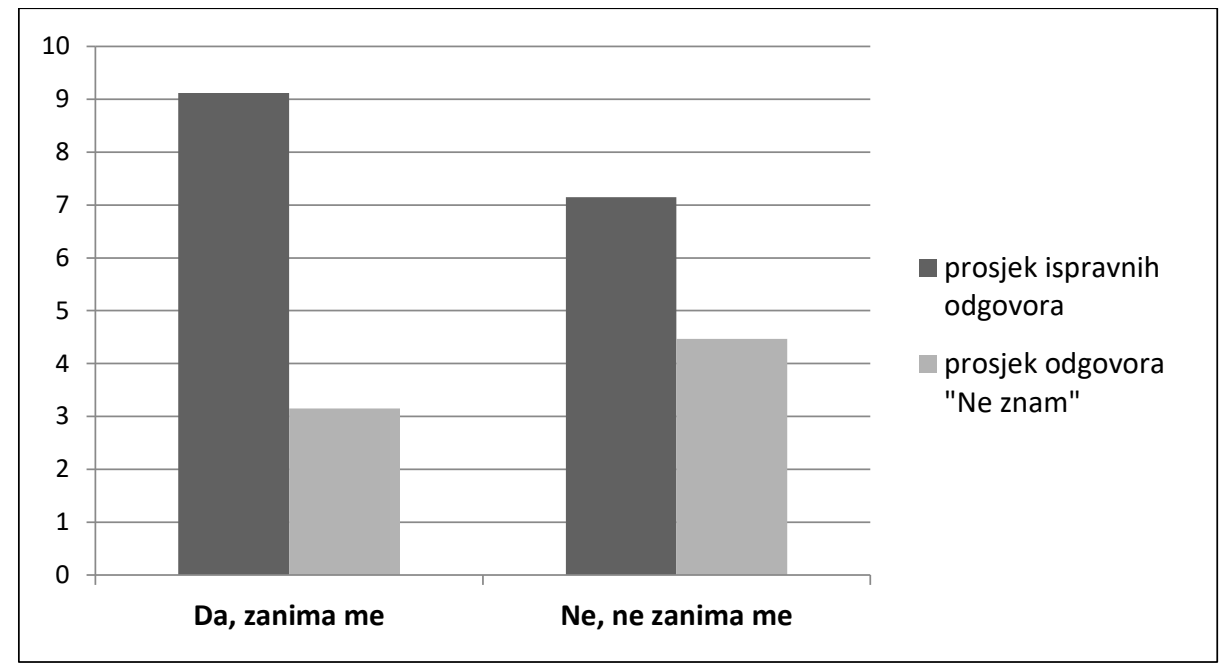

Odnos znanja o homoseksualnoj orijentaciji, samoefikasnosti i podržavajućih ponašanja prema učenicima homoseksualne orijentacije

Nadalje, istraženo je kakav je odnos između znanja nastavnika o homoseksualnoj orijentaciji, njihove samoefikasnosti u radu s homoseksualnim učenicima i njihovih podržavajućih ponašanja. Deskriptivni podaci i korelacije između navedenih varijabli prikazani su u Tablici 2. Nastavnici koji su sudjelovali u ovome istraživanju tek se ponekad upuštaju u podržavajuća ponašanja prema učenicima homoseksualne orijentacije, pri čemu su najviše skloni koristiti materijale koji ne sadrže negativan jezik ili slike povezane s homoseksualnim osobama (njih $77.8 \%$ ). Oko $70 \%$ nastavnika navodi da često ili gotovo uvijek zagovara prava i zaštitu homoseksualnih osoba te korištenje točne terminologije kad se govori o njima. U situacijama kad učenici ili kolege/članovi osoblja koriste homofobne izraze odmah reagira $68.7 \%$ nastavnika, iako tek njih $43.8 \%$ (manje od polovice) izvještava da to radi gotovo uvijek, dok njih oko trećine (31.8\%) ne reagira gotovo nikad ili samo ponekad. Aktivniji oblici podržavajućih ponašanja koji zahtijevaju veći stupanj truda i više vremena nastavnika manje su zastupljeni. Tako manje od $10 \%$ nastavnika koristi 
vizualne znakove koji označavaju podršku homoseksualnim učenicima, npr. posteri, plakati, simboli; osigurava učenicima pristup časopisima, brošurama $i$ ostalim materijalima koji raspravljaju o temama i problemima homoseksualnih osoba; ili bira sudjelovati u edukacijama koje pomažu da efikasnije rade s homoseksualnim učenicima. Tek se otprilike četvrtina nastavnika (26.6\%) trudi da su homoseksualne teme reprezentirane u nastavnome sadržaju i raspravama.

Samoefikasnost nastavnika povezana $\mathrm{s}$ temom homoseksualne orijentacije također nije posebno visoka. U prosjeku su nastavnici umjereno sigurni u to da se mogu nositi sa situacijama nasilja na osnovi seksualne orijentacije, dok su jedva sigurni $u$ to da učenike mogu poučavati temama povezanima s homoseksualnom orijentacijom.

\section{Tablica 2.}

Deskripcija i međusobne korelacije znanja nastavnika o homoseksualnosti, samoefikasnosti i pružanja podrške homoseksualnim učenicima $(N=267)$

\begin{tabular}{lcrcc}
\hline & 1. & 2. & 3. & 4. \\
\hline 1. Znanje & - & .20 & .37 & .46 \\
2. Samoefikasnost u nošenju s nasiljem & & - & .54 & .40 \\
3. Samoefikasnost u poučavanju & & & - & .56 \\
4. Podržavajuća ponašanja & & & & - \\
\hline$M$ & 8.25 & 69.80 & 57.25 & 2.38 \\
$S D$ & 3.34 & 18.51 & 29.12 & 0.66 \\
Min. & 0 & 0 & 0 & 1 \\
Max. & 14 & 100 & 100 & 4 \\
\hline
\end{tabular}

Napomena: Sve korelacije značajne su na razini rizika manjoj od .01 \%.

U skladu s očekivanjima, sve varijable međusobno značajno pozitivno koreliraju $(p<.01)$. Što sudionici imaju više znanja o homoseksualnoj orijentaciji, to imaju viši osjećaj samoefikasnosti i u nošenju s nasiljem i u poučavanju te izvještavaju o upuštanju u više podržavajućih ponašanja. Za provjeru hipoteza o prediktivnoj ulozi znanja i samoefikasnosti te o posredničkoj ulozi samoefikasnosti u objašnjavanju povezanosti između znanja nastavnika o homoseksualnosti i količine njihovih podržavajućih ponašanja za homoseksualne učenike najprije je provedena hijerarhijska regresijska analiza gdje je u prvome koraku uvrštena varijabla znanja, u drugome koraku oba faktora samoefikasnosti, a kao kriterijska varijabla uvrštena su podržavajuća ponašanja (v. Tablicu 3.).

Rezultati pokazuju da je znanje o homoseksualnoj orijentaciji značajan prediktor upuštanja u podržavajuća ponašanja prema učenicima homoseksualne orijentacije koji samostalno objašnjava $21 \%$ varijance kriterija. Oni nastavnici koji imaju više znanja skloniji su upuštati se u podržavajuća ponašanja. Dodavanje samoefikasnosti u drugome koraku objašnjava dodatnih $19 \%$ varijance kriterija te snižava beta koeficijent znanja, što upućuje na moguću medijacijsku ulogu samoefikasnosti koju smo provjerili dodatnom analizom. 


\section{Tablica 3.}

Rezultati hijerarhijske regresijske analize s podržavajućim ponašanjima nastavnika prema homoseksualnim učenicima kao kriterijem $(N=243)$

\begin{tabular}{llcc}
\hline Prediktori & & 1. korak & 2. korak \\
\hline Znanje & $\beta$ & $.46^{* * *}$ & $.29^{* * * *}$ \\
Samoefikasnost u nošenju s izazovima & $\beta$ & & $.13^{*}$ \\
Samoefikasnost u poučavanju & $\beta$ & & $.38^{* * *}$ \\
\hline Kriterij & & & \\
\hline Podržavajuća ponašanja & $R$ & $.46^{* * *}$ & $.63^{\text {**** }}$ \\
& $R^{2}$ & $.21^{* * *}$ & $.40^{* * *}$ \\
& $\Delta R^{2}$ & & $.19^{* * *}$ \\
\hline
\end{tabular}

Napomena: ${ }^{*} p<.05 ;{ }^{* * *} p<.001$.

Medijacijska analiza metodom bootstrapping (korištenjem dodatka PROCESS MACRO u programu IBM SPSS; Preacher i Hayes, 2008) pokazuje da je samoefikasnost u poučavanju o homoseksualnosti značajan medijator odnosa između znanja o homoseksualnosti i podržavajućih ponašanja nastavnika prema homoseksualnim učenicima $(b=0.03, \mathrm{LLCI}=0.015, \mathrm{ULCI}=0.043)$. S druge strane, iako postoji značajna povezanost između znanja i samoefikasnosti u nošenju s nasiljem $(b=1.04, \mathrm{LLCI}=0.354, \mathrm{ULCI}=1.722)$ te samoefikasnosti u nošenju s nasiljem i podržavajućih ponašanja ( $b=0.005, \mathrm{LLCI}=0.006, \mathrm{ULCI}=0.112)$, indirektni efekt samoefikasnosti u nošenju s nasiljem nije značajan $(b=0.0052$, LLCI = -0.0004, ULCI = 0.013). Znanje o homoseksualnosti nakon uvođenja faktora samoefikasnosti i dalje ima samostalan doprinos u objašnjavanju varijance podržavajućih ponašanja $(b=0.06)$, uz interval pouzdanosti od LLCI $=0.036$ do $\mathrm{ULCI}=0.078$, što ukazuje na to da je samoefikasnost u poučavanju djelomični medijator odnosa znanja i podržavajućih ponašanja (Slika 3.).

\section{Slika 3.}

Prikaz medijacijskoga učinka samoefikasnosti u poučavanju o homoseksualnosti $i$ samoefikasnosti u nošenju s nasiljem u odnosu između nastavničkoga znanja o homoseksualnosti i njihovih podržavajućih ponašanja prema učenicima homoseksualne orijentacije $(N=243)$

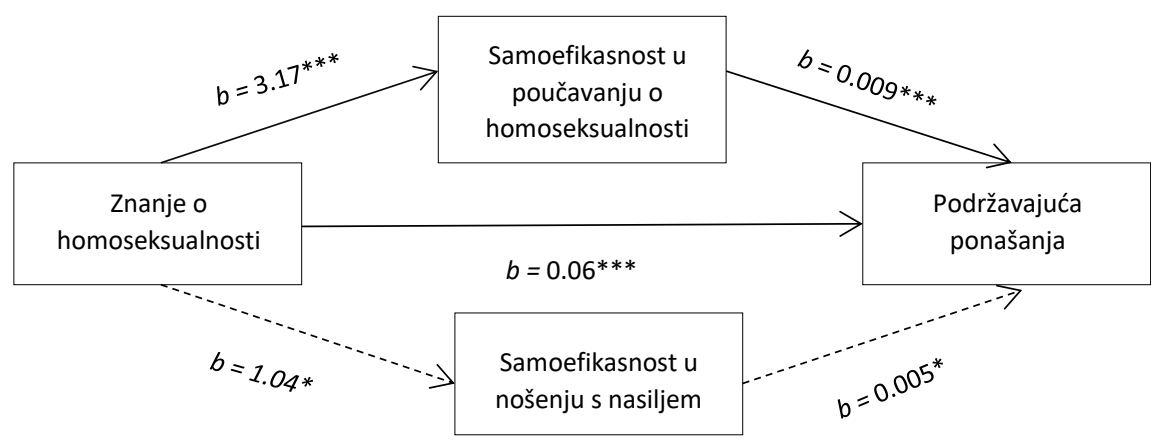

Napomena: Isprekidanom linijom označen je neznačajan medijacijski efekt; ${ }^{*} p<.05,{ }^{* * *} p<.001$. 


\section{Rasprava}

Prvi je cilj ovoga istraživanja bio ispitati znanje srednjoškolskih nastavnika o homoseksualnoj orijentaciji. U prosjeku nastavnici su na Skali znanja o homoseksualnoj orijentaciji imali $59 \%$ ispravnih odgovora, što bi se moglo ocijeniti jedva prolaznom ocjenom ako bi se pratio uvriježeni školski sustav ocjenjivanja. Prema postignutoj dominantnoj vrijednosti sudionici su najčešće imali 10, odnosno $71 \%$ ispravnih odgovora. Takvi su rezultati u skladu s istraživanjem Savage i suradnika (2004), gdje se pokazalo da školski psiholozi imaju nisko do umjereno znanje o homoseksualnim osobama i problemima s kojima se one susreću, a slične su rezultate dobili i Riggs i suradnici (2011) na uzorku studenata učiteljskih fakulteta.

No nastavnici nisu na svim česticama pokazali jednaku količinu znanja, pogrešnoga znanja i biranja odgovora $\mathrm{Ne}$ znam. Najveće postotke ispravnih odgovora sudionici su dali na česticama povezanima s mitovima o uzroku homoseksualnosti, pri čemu znaju da se seksualna orijentacija ne može promijeniti terapijskim postupcima ili molitvom te da zlostavljanje u djetinjstvu ne uzrokuje homoseksualnu orijentaciju. Više od dvije trećine nastavnika zna i da homoseksualne osobe ne mogu loše utjecati na razvoj djece, kao i da ne žele privući druge $u$ homoseksualni stil života.

Iako takvi rezultati ulijevaju optimizam, odgovori sudionika na nekim drugim česticama zabrinjavaju. Najveći broj sudionika pogrešno je odgovorio na pitanja o seksualnome ponašanju homoseksualnih osoba povezana s promiskuitetnim ponašanjem, njihovom zaraženošću HIV-om i čestinom seksualnoga zlostavljanja učenika. Ipak, treba naglasiti da većina onih koji nisu dali ispravan odgovor nije dala pogrešan odgovor, već je odgovorila s Ne znam. Općenito, samo $10.5 \%$ sudionika nijednom nije odabralo odgovor Ne znam prilikom odgovaranja na pitanja znanja, dok je njih $45.3 \%$ odgovorilo Ne znam četiri puta ili više. Takvi rezultati mogu upućivati na veću količinu nesigurnosti u svoje znanje nego sigurnosti u pogrešne informacije kod srednjoškolskih nastavnika te pokazuju da postoji velik prostor za proširivanje znanja nastavnika kroz različite edukacije i radionice. To je još naglašenije uzmemo li u obzir dobiveni nalaz da su čitanje edukativnih materijala nakraju ovoga istraživanja češće odabirali oni nastavnici koji imaju veće znanje i manje su nesigurni u svoje znanje.

Dosadašnja istraživanja pokazala su da i znanje i samoefikasnost imaju važnu ulogu u predviđanju ponašanja nastavnika u kontekstu rada s homoseksualnim učenicima (Greytak i Kosciw, 2014; Nappa i sur., 2017; Swanson i Gettinger, 2016). U istraživanju Pérez-Testor i suradnika (2010) pokazano je da se i nastavnici koji nemaju predrasude prema homoseksualnim osobama i dalje osjećaju neugodno pri kontaktu s njima jer nisu sigurni kako se ponašati. S time u skladu je i naš nalaz da nastavnici koji imaju bolje znanje o homoseksualnoj orijentaciji imaju viši osjećaj samoefikasnosti za nošenje $\mathrm{s}$ nasiljem na osnovi seksualne orijentacije te veću samoefikasnost za poučavanje o temi homoseksualnosti, dok su i znanje i obje 
specifične samoefikasnosti značajni prediktori višega stupnja uključivanja u podržavajuća ponašanja prema homoseksualnim učenicima. Dodatno, rezultati provedene medijacijske analize ukazuju na to da faktor samoefikasnosti $u$ poučavanju ima ulogu medijatora u objašnjavanju te povezanosti, dok drugi faktor samoefikasnosti nema značajnu medijacijsku ulogu. Također, budući da je direktni efekt znanja o homoseksualnosti u predviđanju upuštanja u podržavajuća ponašanja ostao značajan i nakon uvođenja medijatora, riječ je o djelomičnoj medijaciji. Dakle, čini se da što nastavnici imaju veće znanje, češće se i uključuju u podržavajuće aktivnosti, djelomično upravo zbog toga što imaju i veću razinu samoefikasnosti u poučavanju. Zanimljivo je da, iako se generalno nastavnici osjećaju samoefikasnije za nošenje $\mathrm{s}$ nasiljem nego za poučavanje $(t=8.268, p<.001)$, jedino se samoefikasnost $u$ poučavanju o homoseksualnim temama pokazala značajnim posredničkim mehanizmom u odnosu između znanja i podržavajućih ponašanja.

Jedno od objašnjenja nalaza da se nastavnici osjećaju samoefikasnije u nošenju s nasiljem na osnovi seksualne orijentacije možemo pronaći i u tome što su najsnažniji izvor samoefikasnosti iskustva ovladavanja (Bandura, 1994). Nastavnici se u svojemu radu često susreću s nasiljem među učenicima pa se pretpostavlja da su imali prilike uvjeriti se da su sposobni nositi se s takvim izazovima čak i kad nije riječ o učenicima homoseksualne orijentacije. Osim toga, postoje jasni školski protokoli koji nastavnicima pružaju smjernice kako se ponašati u slučaju nasilja. $S$ druge strane, budući da su teme povezane s homoseksualnom orijentacijom rijetko dio školskoga kurikula (Brumen, 2012), nastavnici najvjerojatnije nemaju toliko prilike tomu poučavati učenike ili organizirati rasprave na tu temu pa ne čudi da osjećaju manju samoefikasnost $u$ tome području. Dodatno, prema izvješću pravobraniteljice za ravnopravnost spolova (2016) samo četvrtina razrednika koji su predavali teme u okviru zdravstvenoga odgoja (koji uključuje i seksualnu orijentaciju) smatra se dovoljno kompetentnima da ih mogu obraditi na kvalitetan način, što govori u prilog takvoj interpretaciji. Taj je nalaz bitan zbog toga što je upravo samoefikasnost povezana s poučavanjem o temi homoseksualnosti više povezana $\mathrm{s}$ podržavajućim ponašanjima nastavnika za homoseksualne učenike $\mathrm{u}$ odnosu na samoefikasnost u nošenju s nasiljem povezanim s istom temom.

Dobiveni nalaz da se samo samoefikasnost u poučavanju o homoseksualnosti, a ne i samoefikasnost u nošenju s nasiljem pokazala značajnim medijatorom povezanosti znanja i podržavajućih ponašanja u skladu je s Bandurinom (1994) teorijom koja navodi da više specifično definirana samoefikasnost ima bolju prediktivnu vrijednost. Logično je da je znanje o nekoj temi više povezano sa samoefikasnošću u poučavanju o toj temi te je to jedno od mogućih objašnjenja bolje posredničke uloge toga faktora samoefikasnosti. S druge strane, s obzirom na to da se nastavnici svakodnevno u radu susreću s različitim vrstama vršnjačkoga nasilja, vjerojatno nasilje na osnovi seksualne orijentacije ne doživljavaju drugačijim u odnosu na bilo koju drugu vrstu nasilja (npr. na temelju fizičkoga izgleda, vjere, etničke pripadnosti itd.). Takve su rezultate dobili i Lauermann i König (2016) u 
istraživanju sindroma izgaranja kod nastavnika, gdje je samo specifična samoefikasnost, ali ne i ona generalna, imala ulogu medijatora u vezi između pedagoških znanja i izgaranja na radnome mjestu. Međutim, znanje o homoseksualnosti i dalje zadržava značajan samostalan doprinos u objašnjavanju čestine uključivanja nastavnika u podržavajuća ponašanja, što podržava raniji zaključak da su nastavnicima potrebne dodatne edukacije o homoseksualnoj orijentaciji i specifičnostima u radu s homoseksualnim učenicima.

Također, rezultati pokazuju da se nastavnici to rjeđe upuštaju u podržavajuće aktivnosti što više vremena i truda one od njih zahtijevaju. Taj je nalaz sukladan onomu dobivenomu u istraživanju Huić i suradnika (2016) na uzorku opće populacije heteroseksualnih osoba. Jedan od razloga zbog kojih je važno da nastavnici aktivno izražavaju svoju podršku homoseksualnim učenicima je i to što takva ponašanja olakšavaju homoseksualnim osobama neke od teških procesa kroz koje obično prolaze u periodu adolescencije. Primjerice, to je razdoblje kad donose odluku o otkrivanju svoje seksualne orijentacije drugima, a pozitivne reakcije na to otkrivanje povezane su s višim samopoštovanjem, većim zadovoljstvom životom, nižom anksioznošću i manjim brojem depresivnih simptoma (Halpin i Allen, 2004; Lehavot i Simoni, 2011). Prema Newman i suradnicima (2008) prisutnost LGBT podržavajućih simbola i znakova pokazatelj je otvorenosti prema različitim seksualnim orijentacijama i olakšava odluku o otkrivanju. No čak $69.6 \%$ nastavnika koji su sudjelovali u našemu istraživanju nikad ne koristi, a $23.1 \%$ nastavnika samo ponekad koristi vizualne znakove koji označavaju podršku homoseksualnim učenicima. Takvi rezultati sukladni su onima koje su dobili Swanson i Gettinger (2016), gdje je samo $31 \%$ nastavnika reklo da koristi vizualne znakove u svrhu podrške LGBT učenicima.

\section{Ograničenja i praktične implikacije istraživanja}

Unatoč rezultatima koji su potvrdili očekivanja važno je spomenuti da ovo istraživanje ima i određene nedostatke. Za početak, zbog načina regrutiranja sudionika uzorak ovoga istraživanja bio je prigodan, što ograničava generalizaciju rezultata. Također, podaci su prikupljani online metodom. Takva je metoda izabrana da bi se došlo do demografski različitijega uzorka, a budući da je riječ o kontroverznoj temi, sudionicima je omogućeno da neometano i bez znanja drugih pristupe istraživanju. Usto, Gosling i Mason (2015) u svojemu radu ističu da prednosti prikupljanja podataka putem interneta nadilaze nedostatke te metode.

I sam period prikupljanja podataka bio je vrlo turbulentan za osobe koje su pripadnici seksualnih i rodnih manjina u Hrvatskoj (homoseksualne, biseksualne, transseksualne, transrodne osobe itd.). U travnju 2018. godine ratificirana je Istanbulska konvencija, što je izazvalo mnogobrojne prosvjede i javne polemike. Iako rasprava o sadržaju i problematici Istanbulske konvencije i njezine povezanosti s LGBT osobama nadilazi mogućnosti ovoga rada, smatramo da je moguće da je 
njezina ratifikacija do koje je došlo baš uoči prikupljanja podataka mogla utjecati na uzorak. Moguće je da su se određene skupine ljudi zbog toga češće odlučile uključiti $\mathrm{u}$ ovo istraživanje (oni s ekstremnijim stavovima), dok su se neki drugi možda odlučili ne uključiti zbog prezasićenosti temama povezanima s LGBT populacijom. Nadalje, s obzirom na to da je riječ o korelacijskome nacrtu, nalazi se ne smiju interpretirati kroz uzročno-posljedične odnose, nego se može govoriti samo u terminima povezanosti. Usto, korištena je metoda samoiskaza koja je podložna socijalno poželjnomu odgovaranju te smo od sudionika retrospektivno tražili da se prisjete čestine izvođenja određenih ponašanja, što je također moglo utjecati na kvalitetu njihovih iskaza. Još jedno od ograničenja ovoga istraživanja odnosi se na korištene instrumente. Iako su skale znanja i samoefikasnosti pokazale zadovoljavajuću i visoku pouzdanost tipa unutarnje konzistencije, budući da su konstruirane za potrebe ovoga istraživanja, bilo bi potrebno detaljnije ispitati njihovu valjanost.

Unatoč nedostacima ovo je istraživanje dalo korisne rezultate i važnu osnovu za daljnja istraživanja osobina i iskustava nastavnika u radu s homoseksualnim učenicima. Konkretno, ukazalo je na to da su nastavnici prilično nesigurni u svoje znanje, a oni koji više znaju češće odabiru svoje znanje proširiti. Također, uputilo je na to da su znanje i samoefikasnost povezani $s$ podržavajućim ponašanjima nastavnika. To je važan nalaz upravo zbog ranije predstavljenih razloga prema kojima je socijalna podrška izrazito bitna za različite aspekte dobrobiti homoseksualnih osoba. Iako se ne može zaključivati o uzročno-posljedičnim odnosima, postoje naznake da bi se treninzima za povećanje znanja nastavnika moglo utjecati na njihovu samoefikasnost, a samim time i ponašanja. Primjerice, Greytak i suradnici (2013) pokazali su da i kratak dvosatni trening ima značajne pozitivne učinke na stavove i samoefikasnost nastavnika u pružanju podrške LGBT učenicima u kreiranju inkluzivnoga školskog okruženja. Riggs i suradnici (2011) također su pokazali da su se nakon kombinirane kognitivno-afektivne intervencije znanja, stavovi i očekivana ponašanja nastavnika povećali u odnosu na kontrolnu skupinu. Takvi nalazi daju dodatnu potporu ranijoj raspravi o potrebi daljnje edukacije nastavnika o različitim specifičnostima homoseksualnih učenika, a dodatan je pokazatelj i činjenica da je skoro trećina sudionika našega istraživanja izjavila da predaje barem jednomu homoseksualnom učeniku.

Ovo je istraživanje bilo usmjereno na srednjoškolske nastavnike upravo zbog toga što se tijekom srednje škole često događaju najveće promjene kod mladih homoseksualnih osoba. U budućnosti bi trebalo provesti istraživanje i kod osnovnoškolskih učitelja jer i oni imaju vrlo važnu ulogu u kreiranju pozitivne školske klime i oblikovanju mišljenja učenika od najranije dobi. Također bi bilo korisno istražiti kakva su znanja, stavovi i ponašanja stručnih suradnika u školama jer se i njima učenici često obraćaju za pomoć i podršku. Nadalje, usmjerili smo se na iskustva nastavnika s homoseksualnim učenicima, no budući da postoje istraživanja koja pokazuju da biseksualne i transrodne osobe imaju svoje 
specifičnosti, potrebno je u budućnosti provesti istraživanje kojim bi se i njih obuhvatilo.

Ovo je istraživanje dobar početak budućih istraživanja tako važne, a zanemarene teme u Hrvatskoj. Budući da je skoro trećina sudionika u našemu istraživanju izjavila da ima barem jednoga homoseksualnog učenika u razredu, nastavnici imaju važnu ulogu u pružanju podrške onima koji su često zbunjeni, zlostavljani, isključeni i marginalizirani i u školskome kontekstu i u društvu. Usto, nastavnici imaju veliku mogućnost i odgovornost oblikovanja svojih učenika $u$ mlade ljude otvorenih stajališta i pogleda na ljudsku seksualnost koji se trude nikoga ne diskriminirati.

\section{Literatura}

Alderson, K. G., Orzeck, T. L. i McEwen, S. C. (2009). Alberta high school counsellors' knowledge of homosexuality and their attitudes toward gay males. Canadian Journal of Education, 32(1), 87-117.

American Psychological Association. (2008). Answers to your questions for a better understanding of sexual orientation and homosexuality. http://www.apa.org/topics/ lgbtq/orientation

American Psychological Association. (2011). Guidelines for psychological practice with lesbian, gay and bisexual clients. http://www.apa.org/pi/lgbt/resources/guidelines

Bandura, A. (1994). Self-efficacy. U: V. S. Ramachaudran (Ur.), Encyclopedia of human behavior (Vol. 4, str. 71-81). Academic Press.

Brumen, S. (2012). LGBT tematika u udžbenicima za srednju i osnovnu školu. Lezbijska udruga Kontra, Zagreb.

Collier, K. L., Bos, H. M. i Sandfort, T. G. (2015). Understanding teachers' responses to enactments of sexual and gender stigma at school. Teaching and Teacher Education, 48, 34-43. https://doi.org/10.1016/j.tate.2015.02.002

De Witte, K., Iterbeke, K. i Holz, O. (2019). Teachers' and pupils' perspectives on homosexuality: A comparative analysis across European countries. International Sociology, 34(4), 471-519. https://doi.org/10.1177/0268580919854295

Diamond, L. M. (1998). Development of sexual orientation among adolescent and young adult women. Developmental Psychology, 34(5), 1085-1095. https://doi.org/10.1037/ 0012-1649.34.5.1085

GONG. (2010). Istraživanje političke pismenosti i stavova o pristupanju Hrvatske Europskoj Uniji među učenicima završnih razreda srednjih škola: Tabelarni izvještaj. http://gong.hr/media/uploads/dokumenti/Politikapismenost_tabliniizvjetaj.pdf

Gosling, S. D. i Mason, W. (2015). Internet research in psychology. The Annual Review of Psychology, 66, 877-902. https://doi.org/10.1146/annurev-psych-010814-015321 
Gregus, S. J., Rodriguez, J. H., Pastrana, F. A., Craig, J. T., Mcquillin, S. D. i Cavell, T. A. (2017). Teacher self-efficacy and intentions to use antibullying practices as predictors of children's peer victimization. School Psychology Review, 46(3), 304-319.

Greytak, E. A. i Kosciw, J. G. (2014). Predictors of US teachers' intervention in anti-lesbian, gay, bisexual, and transgender bullying and harassment. Teaching Education, 25(4), 410-426. https://doi.org/10.1080/10476210.2014.920000

Greytak, E. A., Kosciw, J. G. i Boesen, M. J. (2013). Putting the "T" in "Resource": The benefits of LGBT-related school tesources for transgender youth. Journal of LGBT Youth, 10(1-2), 45-63. https://doi.org/10.1080/19361653.2012.718522

Hall, H. (2006). Teach to reach: Addressing lesbian, gay, bisexual, and transgender youth issues in the classroom. The New Educator, 2(2), 149-157. https://doi.org/10.1080/ 15476880600657124

Halpin, S. A. i Allen, M. W. (2004). Changes in psychosocial well-being during stages of gay identity development. Journal of Homosexuality, 47(2), 109-126. https://doi.org/10. 1300/J082v47n02_07

Hatzenbuehler, M. L. (2009). How does sexual minority stigma ,get under the skin“? A psychological mediation framework. Psychological Bulletin, 135(5), 707-730. https://doi.org/10.1037/a0016441

Hodžić, A. i Bijelić, N. (2012). Izvještaj istraživanja o mišljenjima i stavovima prema homoseksualnosti u srednjim školama u Zagrebu. Domino.

Howard, N. M., Horne, A. M. i Jolliff, D. (2001). Self-efficacy in a new training model for the prevention of bullying in schools. Journal of Emotional Abuse, 2(2-3), 181-191. https://doi.org/10.1300/J135v02n02_11

Huić, A., Jelić, M. i Kamenov, Ž. (2016). Što predviđa spremnost heteroseksualnih osoba na pozitivno i negativno ponašanje prema osobama homoseksualne orijentacije? Kriminologija i socijalna integracija, 23(2), 79-109.

Jugović, I. i Ančić, B. (2013). Effects of religiosity and spirituality on gender roles and homonegativity in Croatia and Slovenia. U: N. Furlan Štante i M. Harcet (Ur.), Spirituality of Balkan women breaking boundaries: The voices of women of exYugoslavia (str. 91-115). Annales University Press of the Science and Research Centre of Koper.

Jugović, I. i Pikić, A. (2006). Nasilje nad lezbijkama, gejevima i biseksualnim osobama u Hrvatskoj. Lezbijska grupa Kontra, Zagreb.

Kamenov, Ž., Jelić, M. i Huić, A. (2016). Problemi i izazovi seksualnih manjina u Hrvatskoj. FF Press.

Kosciw, J. G., Greytak, E. A., Giga, N. M., Villenas, C. i Danischewski, D. J. (2016). The 2015 National School Climate Survey: The experiences of lesbian, gay, bisexual, transgender, and queer youth in our nation's schools. GLSEN. https://files.eric.ed.gov/ fulltext/ED574780.pdf 
Kuliš, I. i Petrović, D. (2018). Istraživanje povezanosti nekih obrazovnih faktora i stavova srednjoškolaca o osobama homoseksualne orijentacije. Psyche: Časopis Kluba studenata psihologije ,,STUP“, 1(1), 9-16.

Lauermann, F. i König, J. (2016). Teachers' professional competence and wellbeing: Understanding the links between general pedagogical knowledge, self-efficacy and burnout. Learning and Instruction, 45, 9-19. https://doi.org/10.1016/j.learninstruc. 2016.06.006

Lehavot, K. i Simoni, J. M. (2011). The impact of minority stress on mental health and substance use among sexual minority women. Journal of Consulting and Clinical Psychology, 79(2), 159-170. https://doi.org/10.1037/a0022839

McCabe, P. C., Rubinson, F., Dragowski, E. A. i Elizalde-Utnick, G. (2013). Behavioral intention of teachers, school psychologists, and counselors to intervene and prevent harassment of LGBTQ youth. Psychology in the Schools, 50(7), 672-688. https://doi.org/10.1002/pits.21702

Meyer, I. H. (2003). Prejudice, social stress, and mental health in lesbian, gay, and bisexual populations: Conceptual issues and research evidence. Psychological Bulletin, 129(5), 674-697. https://doi.org/10.1037/0033-2909.129.5.674

Milković, M. (2013). Brutalna stvarnost: Istraživanje o nasilju, diskriminaciji i zločinu iz mržnje protiv LGBTIQ osoba u Hrvatskoj. Zagreb Pride.

Murdock, T. B. i Bolch, M. B. (2005). Risk and protective factors for poor school adjustment in lesbian, gay, and bisexual (LGB) high school youth: Variable and person-centered analyses. Psychology in the Schools, 42(2), 159-172. https://doi.org/10.1002/pits.20054

Nappa, M. R., Palladino, B. E., Menesini, E. i Baiocco, R. (2017). Teachers' reaction in homophobic bullying incidents: The role of self-efficacy and homophobic attitudes. Sexuality Research and Social Policy, 15(2), 208-218. https://doi.org/10.1007/s13178017-0306-9

Newman, P. A., Bogo, M. i Daley, A. (2008). Self-disclosure of sexual orientation in social work field education: Field instructor and lesbian and gay student perspectives. The Clinical Supervisor, 27(2), 215-237. https://doi.org/10.1080/07325220802487881

Pérez-Testor, C., Behar, J., Davins, M., Sala, J. L. C., Castillo, J. A., Salamero, M., Alomar, E. i Segarra, S. (2010). Teachers' attitudes and beliefs about homosexuality. The Spanish Journal of Psychology, 13(1), 138-155. https://doi.org/10.1017/S1138741600003735

Pravobraniteljica za ravnopravnost spolova. (2016). Sažetak izvješća o radu pravobraniteljice za 2015. https://www.prs.hr/attachments/article/1923/Sa\%C5\%BEetak\%20Izvje\% C5\%A1\%C4\%87a\%20o\%20radu\%20Pravobraniteljice\%20za\%20ravnopravnost $\% 20$ spolova\%20za\%202015. .pdf

Preacher, K. J. i Hayes, A. F. (2008). Contemporary approaches to assessing mediation in communication research. U: A. F. Hayes, M. D. Slater i L. B. Snyder (Ur.), The Sage sourcebook of advanced data analysis methods for communication research (str. 1354). Sage Publications, Inc. https://doi.org/10.4135/9781452272054.n2

Reeve, J. (2010). Razumijevanje motivacije i emocija. Naklada Slap. 
Riggs, A. D., Rosenthal, A. R. i Smith-Bonahue, T. (2011). The impact of a combined cognitive-affective intervention on pre-service teachers' attitudes, knowledge, and anticipated professional behaviors regarding homosexuality and gay and lesbian issues. Teaching and Teacher Education, 27(1), 201-209. https://doi.org/10.1016/j.tate. 2010.08.002

Russell, S. T., Seif, H. i Truong, N. L. (2001). School outcomes of sexual minority youth in the United States: Evidence from a national study. Journal of Adolescence, 24, 111127. https://doi.org/10.1006/jado.2000.0365

Savage, T. A., Prout, H. T. i Chard, K. M. (2004). School psychology and issues of sexual orientation: Attitudes, beliefs, and knowledge. Psychology in the Schools, 41(2), 201210. https://doi.org/10.1002/pits.10122

Swanson, K. i Gettinger, M. (2016). Teachers knowledge, attitudes, and supportive behaviors toward LGBT students: Relationship to gay-straight alliances, antibullying policy, and teacher training. Journal of LGBT Youth, 13(4), 326-351. https://doi.org/10.1080/ 19361653.2016.1185765

Štulhofer, A. i Rimac, I. (2009). Determinants of homonegativity in Europe. The Journal of Sex Research, 46(1), 24-32. https://doi.org/10.1080/00224490802398373

Takács, J. i Szalma, I. (2013). How to measure homophobia in an international comparison. Družboslovne razprave, 29(73), 11-42.

Wells, J. W. i Franken, M. L. (1987). University students' knowledge about and attitudes toward homosexuality. Journal of Humanistic Counseling, Education \& Development, 26(2), 81-95. https://doi.org/10.1002/j.2164-4683.1987.tb00316.x

Whitman, J. S., Horn, S. S. i Boyd, C. J. (2007). Activism in the schools: Providing LGBTQ affirmative training to school counselors. Journal of Gay \& Lesbian Psychotherapy, 11(3-4), 143-154. https://doi.org/10.1300/J236v11n03_08

Yoon, J. (2004). Predicting teacher interventions in bullying situations. Education and Treatment of Children, 27(1), 37-45.

\title{
The Mediating Role of Self-Efficacy on the Relationship between High School Teachers' Knowledge about Homosexuality and Their Supportive Behaviours towards Homosexual Students
}

\begin{abstract}
The goal of this study was to examine high school teachers' knowledge about homosexuality and determine if there is a relationship between said knowledge, self-efficacy and the frequency in which they support homosexual students. The study was conducted online, on 267 high-school teachers. We used the Knowledge of Homosexual Orientation Scale, the Self-efficacy in Working with Homosexual Students Scale and The Supportive Behaviours towards Homosexual Students Scale. The results show that high school teachers' knowledge about homosexual orientation is moderate. They also frequently choose the "I don't know" option instead of the wrong one. Furthermore,
\end{abstract}


teachers rarely tend to involve themselves in supportive behaviours and their self-efficacy level is only moderate. Their self-efficacy in their ability to deal with situations of peer violence based on sexual orientation is greater than their feeling of confidence in teaching about homosexuality. Knowledge and both self-efficacy factors significantly predict the frequency of teachers' tendency to involve themselves in supportive behaviours. Teachers with better knowledge about homosexuality are also more involved in supportive behaviours towards homosexual students, but that relationship is partly mediated by their greater self-efficacy in teaching about homosexuality and not by their confidence in dealing with situations of peer violence based on sexual orientation. Results show both knowledge and self-efficacy have an important role in the display of high school teachers' supportive behaviours for homosexual students, who are very much in need of social support.

Keywords: homosexual orientation, knowledge about homosexuality, self-efficacy, supportive behaviours, high school teachers

Primljeno: 15. 7. 2019. 